2. To: (Receiving Organization)

Distribution

5. Proj./Prog./Dept/Div.:

B\&W Hanford Company

8. Originator Remarks:

This document was prepared to close the Unreviewed Safety Question for the 324

Facility related to HEPA Filter Failure.

11. Receiver Remarks:

11A. Design Baseline Document? [] Yes [X] No

None

3. From: (Originating Organization)
B\&W Hanford Company
6. Design Authority/ Design Agent/Cog. Engr.:
M. B. Enghusen

3. From: (Originating Organization)

6. Design Authority/ Design Agent/Cog. Engr.:

M. B. Enghusen
4. Related EDT No.:

NA

7. Purchase Order No.:

NA

9. Equip./Component No.:

NA

10. System/Bldg./Facility:

324 Facility

12. Major Assm. Dwg. No.:

NA

13. Permit/Permit Application No.:

NA

14. Required Response Date:

NA

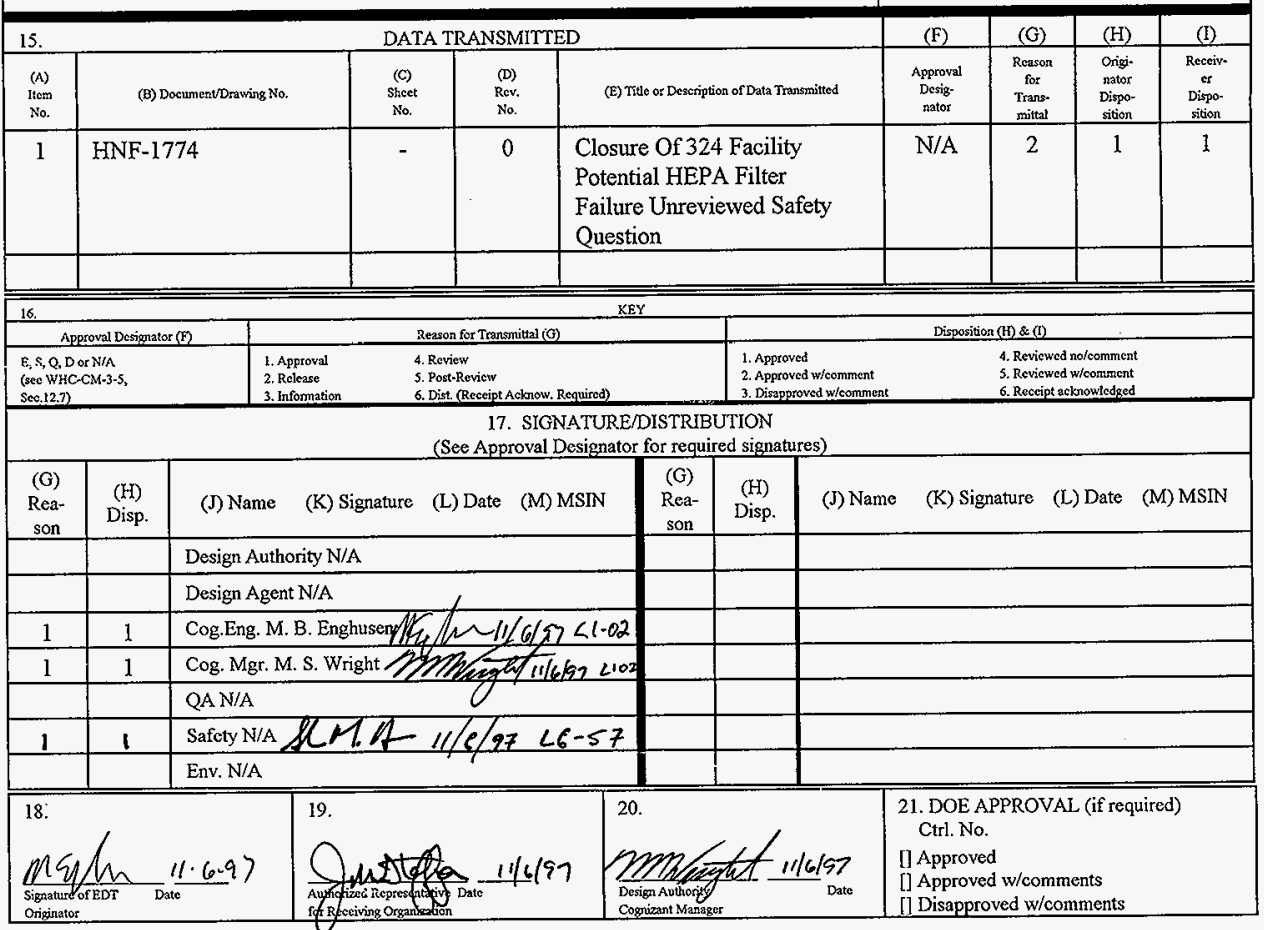

BD-7400-172-2 (05/96) GEF097 


\section{Closure of 324 Facility Potential HEPA Filter Failure Unreviewed Safety Questions}

M. B. Enghusen

B\&W Hanford Company, Richland, WA 99352

U.S. Department of Energy Contract DE-AC06-96RL13200

EDT/ECN: 611750

Org Code: 19200

B\&R Code: EW 3130020
UC: 610

Charge Code: K4M11

Total Pages: $2 z_{y B} 28$

Key Words: HEPA, USQ, High Efficiency Particulate Air, Filter, 324 Building, 324 Facility

Abstract: This document summarizes the activities which occurred to resolve an Unreviewed Safety Question (USQ) for the 324 Facility involving Potential HEPA Filer Breach. The facility ventilation system had the capacity to fail the HEPA filters during accident conditions which would totally plug the filters. The ventilation system fans were modified which lowered fan operating parameters and prevented HEPA filter failures which might occur during accident conditions.

TRADEMARK DISCLAIMER. Reference herein to any specific commercial product, process, or service by trade name, trademark, manufacturer, or otherwise, does not necessarily constitute or imply its endorsement, recommendation, or favoring by the United States Government or any agency thereof or its contractors or subcontractors.

Prinied in the United States of America. To obtain copies of this document, contact: Document Control Services, P.O. Box 950, Mailstop H6-08, Richland WA 99352, Phone (509) 372-2420; Fax (509) 376-4989.

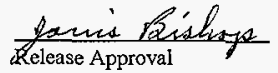

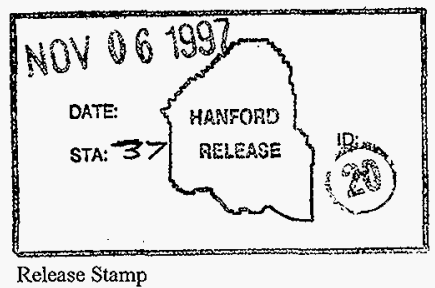

\section{Approved for Public Release}


HNF-1774

Rev. 0

\section{Closure Of 324 Facility Potential HEPA Filter Failure Unreviewed Safety Question}

Prepared By: M. B. Enghusen

$\mathrm{B} \& W$ Hanford Company

November 6, 1997 
HNF-1774

Rev. 0

\section{Table Of Contents}

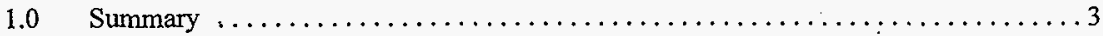

2.0. Background $\ldots \ldots \ldots \ldots \ldots \ldots \ldots \ldots \ldots \ldots \ldots \ldots \ldots \ldots \ldots \ldots \ldots, \ldots \ldots \ldots$

3.0 Unusual Occurrence And Discovery USQ Determination $\ldots \ldots \ldots \ldots \ldots \ldots \ldots$

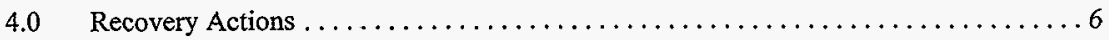

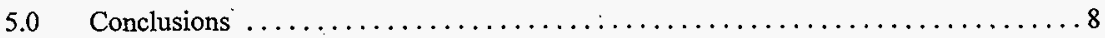

\section{List Of Appendices}

Appendix A Typical Fan Performance Curve $\ldots \ldots \ldots \ldots \ldots \ldots \ldots \ldots \ldots$

Appendix B Work Package For 324 Building Zone I Fan Modifications ............. 11

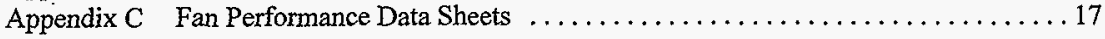


HNF-1774

Rev. 0

\subsection{Summary}

The purpose of this report is to demonstrate that the modifications to the 324 Facility Zone I exhaust ventilation system placed the facility within the assumptions of the 324 Building Safety Analysis Report (SAR), PNL-SAR-324, and that a Discovery Unreviewed Safety Question (USQ) for "324 Facility Potential HEPA Filter Breach" has been resolved.

During the preparation of the 324 Facility Fire Hazard Analysis a fire accident scenario was presented in which a small fire would start in the hot cells which would plug the High Efficiency Particulate Air filters. The filters would fail and contaminated material would be released to the environment. This accident scenario did not match the accident scenarios presented in the 324 Building Safety Analysis Report. The Zone I exhaust system was reviewed by the cognizant plant forces which showed that in 1969 the 324 building hot cell Zone I exhaust system was modified by installing new charcoal filters downstream of the HEPA filters and increasing the size of the exhaust fans. The charcoal filters were installed to remove radioactive gasses and new fans were installed to overcome the charcoal filter air flow resistance. The new exhaust fans were larger and provided higher static pressure and flow capacity. The increased static pressure provided by the fans during no flow conditions was sufficient to fail the Zone I High Efficiency Particulate Air (HEPA) filters if they were to plug during the fire scenarios presented in the draft FHA and the 324 Building SAR.

The failure of the HIEPA filters during a remote fire in the hot cells was not analyzed in the 324 Building SAR. The Plant Review Committee (PRC) reviewed the fan modifications and determined that a Discovery condition existed. The facility was placed in a safe condition and the Unreviewed Safety Question Evaluation (USQE) was completed and reviewed by the PRC which indicated a USQ existed. The USQE was transmitted to DOE which then declared the USQ.

In order to recover from the USQ, the fans were modified in September to reduce the capacity of the fans while maintaining sufficient flow to provide contamination control. The changes to the fans reduced the maximum possible static pressure which ensured the HEPA filters would not fail when plugged with particulates. The fan modifications returned the facility to the conditions presented in the 324 Building SAR and the USQ has been resolved. 
HNF-1774

Rev. 0

\subsection{Background}

In August, 1997, a draft 324 Facility Fire Safety Analysis (FHA) document (HNF-SD-HT-FHA002 , "324 Facility Fire Hazard Analysis") was issued for review by the facility representatives. The draft FHA presented a new accident scenario in which a small localized fire in the hot cells causes an oil filled window to fail. The fire releases the window oil which adds fuel to the fire. The smoke and particulates from the postulated fire contains a sufficient quantity of particulates to plug the High Efficiency Particulate Air (HEPA) filters in the hot cell Zone I exhaust system. The fans would continue to run providing sufficient differential pressure across the plugged HEPA filters to fail the filters. The hot cells would then have an open channel for dispersion of contamination from the process cells to the environment via the main stack.

A review of the Zone I exhaust system was conducted to evaluate this new fire scenario. The review of the Zone I exhaust system showed that in 1969 charcoal filters were installed downstream of the final HEPA filters. The Zone I exhaust fans were replaced at the same time to overcome the additional pressure drop provided by the charcoal filters. According to the installation drawings the new fans were designed to provide a static pressure of 15 inches water gauge (drawing H-3-28596, Revision 1, "HVAC Adsorption System Plan and Details"). This potential static pressure was validated using available vendor information typical of the installed fans. The HEPA filters installed in Zone I exhaust system are nuclear grade and purchased per specifications QPL-51068-7 compliant with MIL-F-068 Section 3.4.4 "Resistance To Pressure". The filters are normally operated up to a maximum of 5 inches water gauge at which time they are replaced. The HEPA filters are capable of handling a maximum of $10 \pm 0.2$ inches of water gauge differential pressure for one hour. The failure of the plugged HEPA filters during accident conditions was therefore considered credible . 
HNF-1774

Rev. 0

\subsection{Unusual Occurrence And Discovery USQ Determination}

The 324 Building Safety Analysis Report (SAR), PNL-SAR-324, analyzes two accident scenarios involving hot cell fires. In section 6.3.1 "Hot Cell Fires" a fire in the hot cells is assumed to produce sufficient smoke to plug the exhaust HEPA filters. The smoke generated by the fire would then migrate into the areas around the hot cells and be routed through the Zone II exhaust system. The HEPA filters in the Zone II exhaust system would prevent the release of material to the environment. The probability of a fire resulting from this scenario is considered high, anticipated, however the consequences are low due to filtered release of material. In section 6.3.2 "Major Fire" a large fire is initiated in Zone II building areas located outside the hot cells. The fire is large enough to cause a hot cell window to fail and the fire to spread into the hot cells. The filters then plug and possibly breach which results in release of unfiltered contamination to the environment. For this accident scenario both the filtered and unfiltered releases from the Zone II exhaust system were analyzed. The probability of a fire resulting from this scenario is considered highly unlikely with a high consequence from the unfiltered release of material to the environment.

The modifications to the Zone I exhaust fans provided the potential for a plugged filter failure which is not analyzed by section 6.3.1 "Hot Cell Fire" accident in the 324 Building SAR. A Plant Review Committee meeting was held August 22, 1997, which concluded that this represented a Discovery condition. The 324 Facility was placed in a safe condition in which all work in hot cells which could initiate a fire was suspended and an Unusual Occurrence report was issued (UO number RL-PHMC-324FAC-1997-0010 and Management Directive 324-MD001 "Control of Hot Work in 324 Facility Stabilization Project"). An Unreviewed Safety Question Evaluation (USQE), number 324-BWHC-97-002, was completed September 1, 1997, to determine if the fan modifications represented conditions which were not analyzed in the current 324 Building SAR. The USQE was reviewed by the Plant Review Committee on September 4, 1997, and the Discovery USQ was identified. Minor comments were also made on the USQE and a the USQE was revised September 4, 1997. The USQE was submitted to DOE (BWHC-9758040, G. O. Hayner to L. J. Olguin, "Unreviewed Safety Question Evaluation For 324 Facility", September 5, 1997 and FDH-9758040 R1, L. J. Olguin to J. E. Mecca, "Unreviewed Safety Question Evaluation For 324 Facility", September 8, 1997). The DOE declared the USQ on September 16, 1997 (97-TPD-177, J. D. Wagner to H. J. Hatch "Contract No. DE-AC06-96RL13200 - Unreviewed Safety Question Evaluation For The 324 Facility"). 
HNF-1774

Rev. 0

\subsection{Recovery Actions}

The hot cell Zone I exhaust system operating parameters were reviewed by management and the cognizant engineer which identified three possible recovery actions:

1. An interlock system could be installed which would monitor the filter differential pressure and shut off the exhaust fans if the filters differential pressure reaches the operating limits.

2. A vacuum breaker damper could be installed which would open when the differential pressure applied to the HEPA filters exceed operating limits thereby protecting the filters from failing.

3. The fans could be reduced in speed which would reduce the maximum differential pressure across the HEPA filters below $10 \mathrm{in}$. WG. while maintaining the current design conditions through the building and maintaining contamination control.

The fan modifications alternative was selected due to simplicity of the change and ability to meet the requirements presented in the 324 building SAR without additional OSR equipment, controls and testing.

The specific performance characteristics of the fans installed at 324 were not available from the vendor information. A typical performance curve for similar type fan operated at a specific fan revolutions per minute (RPM) is shown in Appendix A. If the fan speed is reduced, the performance curve will be lowered and the static pressure provided by the fan at the same flow rates will be reduced. This allows reduction in static pressure provided by the fan while still providing sufficient air flow capacity (at a reduced static pressure) for building contamination control. It needs to be noted that the static pressure at very low or no flow is the main concern of the USQ. This is the condition which represents the plugged filter upstream of the fans. The static pressure provided by the fans at this point is equal to the differential pressure across the HEPA filters. If the static pressure at this very low or no flow condition is greater that the capability of the HEPA filters, the filters will fail. At higher flow rates, the filters are not plugged and the static pressure provided by the fans is distributed across the entire ventilation system. Higher static pressures at the higher flow rates will therefore not cause a filter failure. 


\section{HNF-1774}

Rev. 0

The Zone I fan modifications involved the identification of new sheaves and belts which would reduce the fan speed and corresponding performance curve. The motors used on the fans are constant speed and were not modified or changed. The existing fan speed was measured at 990 revolutions per minute (rpm). The cognizant engineer used vendor supplied tables for performance information to identify a new fan target speed of $740 \mathrm{rpm}$.

New sheaves were ordered and the fans were modified at the end of September, 1997 (work package 3I-97-00823). The operating characteristics of the new fans were tested by closing the blocking damper and measuring the static pressure and flow rates (work package 3I-97-00849, Appendix B) for the first modified fan. All the Zone I fans are identical in construction and performance and the first fan was tested to ensure that the modifications provided the required static pressures and flow rates. The static pressures and flow rates at the different damper positions was taken and recorded in the data sheets provided in Appendix $\mathrm{C}$ and recorded in the work package, Appendix B. The static pressure provided by the fan with the blocking damper closed was 6.67 inches water gauge (WG) at leakage rate of 1449 cubic feet per minute (CFM). As the blocking damper was opened and the flow rate through the fan increased the static pressure increased as expected by the fan operating curves. The static pressure increased from the 6.67 inches WG at 1449 CFM to 9.6 inches WG at 5, 416 CFM. This represents significant flow through the ventilation system and the static pressure is still below the HEPA filter capacity. Additional data was taken up to $10,309 \mathrm{CFM}$. about $1 / 2$ fan capacity, which provided a static pressure of 10.50 inches WG. The data taken at the higher flow rates was considered conservatively high due to interferences from the operating non-modified fans on the modified fan via common inlet and outlet ductwork.

The performance data discussed above provided the information which demonstrated that the HEPA filters would not be subjected with sufficient DP to fail (i.e. static pressure at no or very low flow rates) if they were to plug. The data also showed that the fans had flow capacity, CFM, to support the building operation. The remainder of the fans were modified and the RPM of the fans were checked to ensure that all three Zone I fans were operating at the same speed.

Following all three fan modifications, the flow and differential pressure in the Zone I system was more easily controlled by the dampers. Prior to the modifications, the dampers operated in a mostly closed position and small changes in damper control made large changes in both flow and differential pressure readings in the ductwork. After the fans were modified, the control dampers operated in an open position which provided better flow and differential pressure control. The fan operation also had noticeably lower vibration resulting from both the lower fan speed and reduction in the ductwork turbulence by operating the dampers in a more open position. 


\section{HNF-1774}

Rev. 0

\subsection{Conclusions}

The maximum static pressure which can be provided by the Zone I exhaust fans is well below the limits for the HEPA filter operation. The Zone I HEPA filters will not fail due to particulate loading and the Zone I exhaust system is operating per the conditions presented in the 324 Building SAR. The Discovery USQ has been resolved. An Administrative change to the 324 Building SAR will be prepared which will enhance the Zone I and Zone II exhaust systems description sufficient to prevent similar changes in ventilation design. 
HNF-1774

Rev. 0

Appendix A Typical Fan Performance Curve 


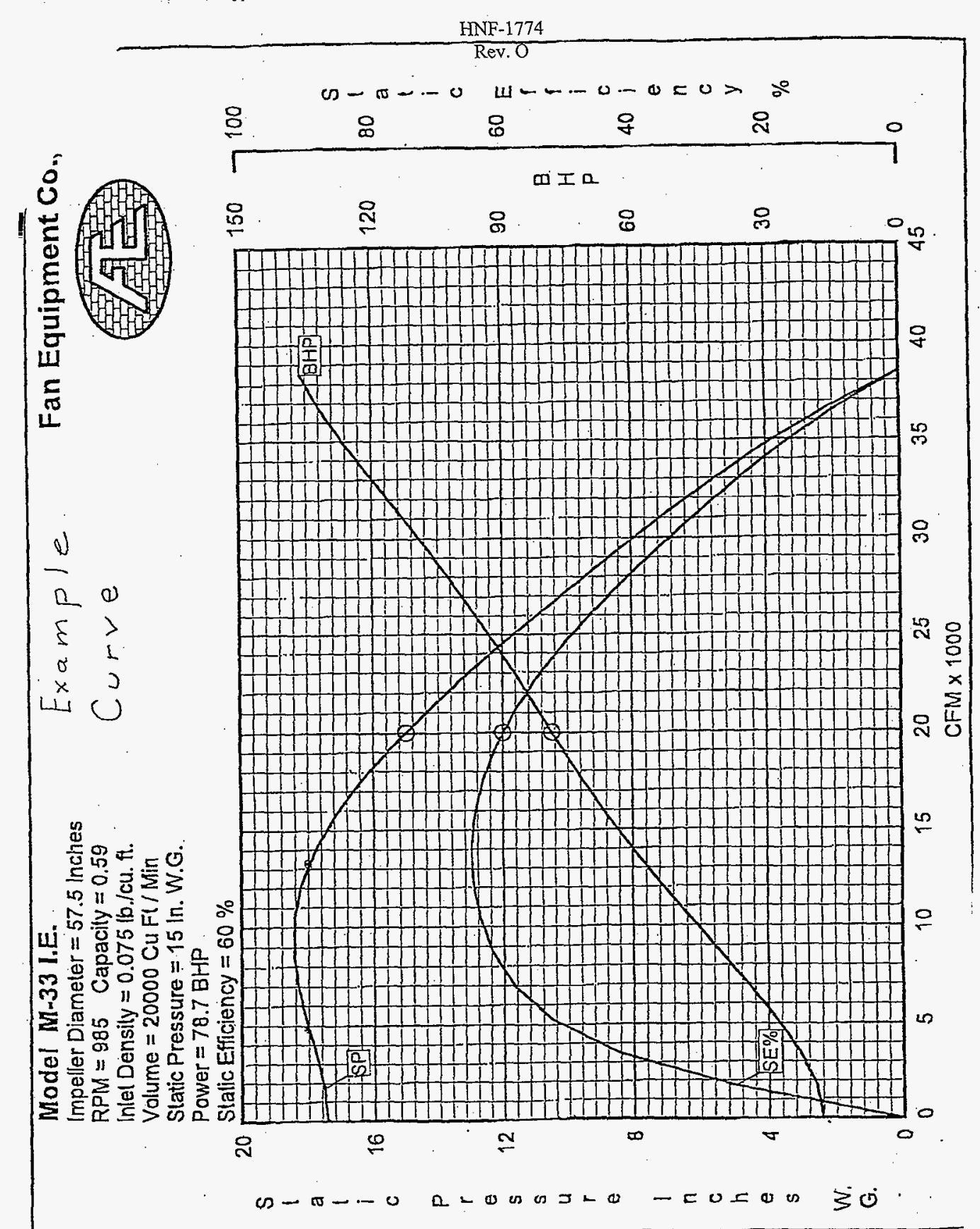




\section{HNF-1774}

Rev. 0

Appendix B Work Package For 324 Building Zone I Fan Modifications 
1. Document Number 31-97-00849/W GENERIC WORK ITEM.

2. Work Item Title ZONE I EXH.FAN PERFORMANCE VERIFICATION

3. Components

$\begin{array}{ll}\text { Component Number } & \text { Name } \\ 3 \mathrm{I}-041060 & 324 * \text { EXHAUST FAN \# } 973 \\ \text { Temporary Number } & \text { Name }\end{array}$

\section{System FAN SUPPLY/EXHAUST FANS}

5. Location
Facility 3 I 324 BUILDING
$\mathrm{B} T \mathrm{dg} / \mathrm{Rm} 324$
Other EAST SIDE Other

6. Symptom, Problem, or Condition

NEED PERFORMANCE DATA TO VERIFY THAT EXHAUST FAN \#973 AS

REQUIRED AND MAINTAIN A STATIC SHUT OFF HEAD OF LESS THAT 10

IN.WG.

WORK WITH JCS PKG. 3I-97-00823.

7. Originator Name GREGONIS, RA

Telephone No. 373-3851 MSIN L1-05

Date

$09 / 11 / 97$

8. Charge Code K4All

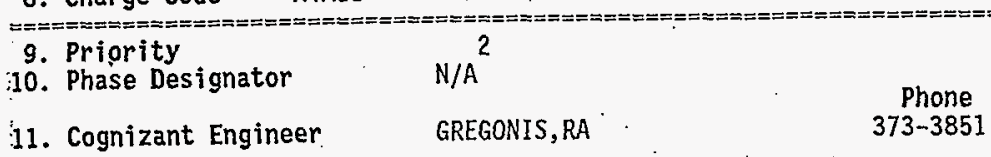

12. Planning Required $\dot{Y}$

13. Screener/Ops Review

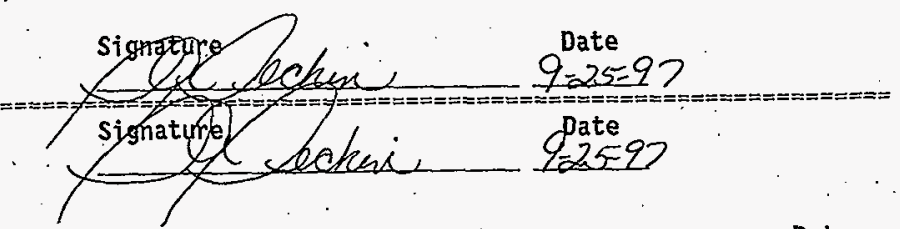

15. Approvals

Code Description

OP OPERATIONS

CE. COGNIZANT ENGINEER

HP HEALTH PHYSICS

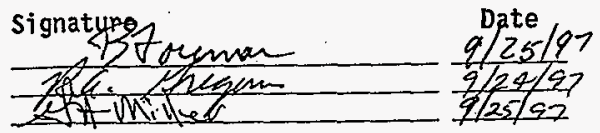

16. Resources Required

Res Code Description

V\&B VENT AND BALANCE

HCT . HOT CELL TECHNICIAN

No.2-Act Hrs

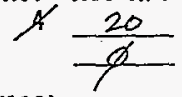


HNF-1774

Rev. $\mathrm{O}$

*** RECORD COPY ***

$\star * *$ RECORD COPY ****

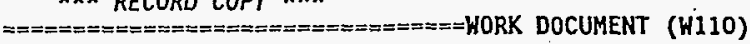

Page: 2

$13: 21: 03 \quad 24$ SEP 1997

1. Document Number 3I-97-00849/W GENERIC WORK ITEM

2. Hork Item Title ZONE I EXH.FAN PERFORMANCE VERIFICATION

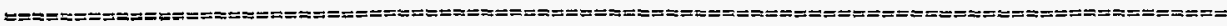
54

Radiation Protection Technicia 1

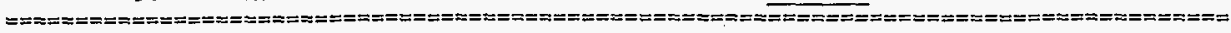


1. Document Number 3I-97-00849/H GENERTC WORK ITEM

2. Work Item Title ZONE I EXH.FAN PERFORMANCE VERIFICATION

17. Pre-Work Review

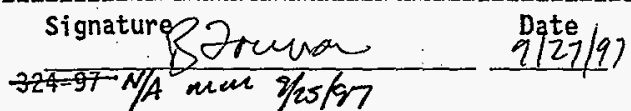

18. Tagout Number

19. Work Release Type, signature 3 Jouman $\$(27) / 17$

20. Work Suspension

21. PIC

PIC 0rg.

Resolution/Retest

$\star * *$ NOTE***

(See Hork Suspension Sheet)

PIC

THIS WORK WILL VERIFY THE PERFORMANCE OF THE MODIFIED ZONE I EXHAUST FANS. JCS PACKAGE 3I-97-823 INSTALLED NEW BELTS AND SHEAVES TO REDUCE THE SPEED OF THE FANS IN ORDER TO DROP THE MAXIMUM SHUT OFF HEAD TO LESS THAN 10 IN. WG. THE DAMPER LINKAGE ON THE DOWNSTREAM BLOCKING DAMPER WILL BE DISCONNECTED AND A VICE GRIP WILL BE INSTALLED TO ALLOW THE MANUAL OPERATION OF THE DAMPER DURING THE TEST. EXHAUST FAN \#973 WILL BE TESTED AT SEVERAL AIR FLOW RATES AND FAN STATIC PRESSURES WILL BE MEASURED. THE RESULTS OF THIS WORK PKG. WILL VERIFY WHETHER OR NOT THE FAN SHUT OFF HEAD HAS BEEN REDUCED BELOW THE MAXIMUM ALLOWABLE STATIC OF 10 IN.WG.

1] PRE-JOB SAFETY MEETING.

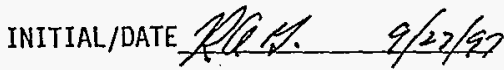

***NOTE: PERFORM WORK PER HVAC COG. ENGR. DIRECTION. USE PROCEDURE 7-GN-056 AS REFERENCE. RECORD MEASUREMENTS ON DATA SHEETS PROVIDEO. TESTING MAY BE TERMINATED AND THE SYSTEM RETURNED TO STABLE NORMAL CONFIGURATION AT ANYTIME AT THE DISCRETION OF. THE COG. ENGINEER.

***NOTE: FAN OPERATIONAL STATUS SHALL BE REDUCED VENTILATION PER PROCEDURE 324-PWR-001 WITH EXHAUST FANS 974 AND 975 OPERATING AND 973 ON STANDBY.

2] INSTALL VICE GRIP PLIARS ON DAMPER SHAFT OF THE BLOCKING DAMPER DOWN STREAM OF THE FAN AND WHILE MAINTAINING THE. DAMPER IN A CLOSED POSITION DISCONNECT THE DAMPER LINKAGE FROM THE DAMPER MOTOR ON EXHAUST FAN \#973. WITH ANOTHER PAIR OF VICE GRIP PLIARS LOCK THE DAMPER IN THE CLOSED POSITION. 
1. Document Number 3I-97-00849/W GENERIC WORK ITEM

2. Work Item TitTe ZONE I EXH. FAN PERFORMANCE VERIFICATION

INITIAL/DAT

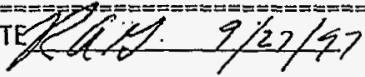

3] START EXHAUST FAN \#973. MANUAL OVERRIDE MAYBE REQUIRED TO KEEP ALL THREE ZONE I EXHAUST FANS RUNNING AT THE SAME TIME.

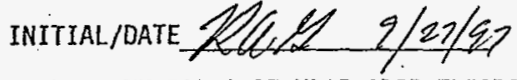

***NOTE: USING BOTH PAIRS OF VICE GRIP FLIARS, ONE AS A MANUAL DAMPER CONTROL HANDLE AND THE OTHER AS A LOCKING DEVICE ADJUST DAMPER TO VARIOUS OPEN POSITIONS AS REQUIRED BELOW. MEASURE AND RECORD DATA ON DATA SHEETS PROVIDED AND IN SPACES PROVIDED BELOW. ADDITIONAL TESTING MY BE REQUIRED AT THE DISCRETTION OF THE HVAC COG. ENGINEER.

\section{4] TESTING}

***NOTE: ALLOW THE HVAC SYSTEM TO COME TO EQUILIBRIUM AFTER DAMPER HAS BEEN MOVED AND VERIFICATION FROM POWER OPERATOR THAT THE HVAC SYSTEM IS OPERATING IN A NORMAL STABLE MODE.

$\begin{array}{llll} & \begin{array}{l}\text { DAMPER } \\ \text { POSITION }\end{array} & \begin{array}{l}\text { FAN STATIC } \\ \text { PRESSURE }\end{array} & \begin{array}{l}\text { EXHAUST AIR } \\ \text { FLOW RATE }\end{array} \\ \text { TEST } 1 & \text { CLOSED } & 6.705 \text { IN.WG. } 44499 \text { CFM } \\ \text { TEST. } 2 & 1 / 8 \text { OPEN } & 7.047 \text { IN.WG. } 4,778 \text { CFM } \\ \text { TEST } 3 & 1 / 4 \text { OPEN } & 7.481 \text { IN.WG. } 3,8470 \text { CFM } \\ \text { TEST } 4 & 3 / 8 \text { OPEN } & 8.158 \text { IN.WG. } 4,460 \text { CFM } \\ \text { TEST } 5 & 1 / 2 \text { OPEN } & 8.826 \text { IN.WG. } 5,281 \text { CFM }\end{array}$

***NOTE: HVAC COG. ENGINEER TO VERIFY SUFFICIENT DATA HAS BEEN TAKEN BEFORE PROCEEDING TO THE NEXT STEP.

5] RETURN EF-973 TO OPERATIONAL STATUS PRIOR TO TEST.

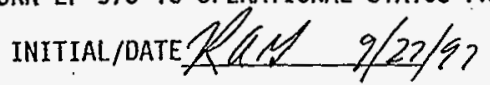

6] RECONNECT DAMPER LINKAGE TO DAMPER OPERATOR AND REMOVE VICE GRIP PLIARS.

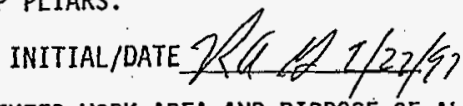

14] HOUSEKEEP WORK AREA AND DISPOSE OF ALL WASTE IN PROPER 
HNF-1774

Rev. O

*** RECORD COPY ***

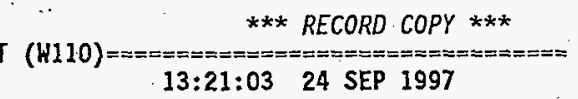

Page: 5

1. Document Number 3i-97-00849/W GENERIC WORK ITEM

2. Work Item Title ZONE I EXH.FAN PERFORMANCE VERIFICATION

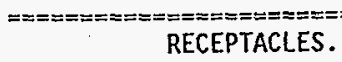

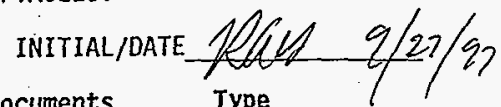

22. Reference Documents $\angle$ CRAFT LOG PRE-JOB SAFETY $\checkmark$ HJHA 7-GN-56 324-PUR-001 324-97-007, REV. 2

23. Field Work Complete

24. Ops_Acceptance

25. Post Review
Type OTHR OTHR OTHR OTHR RWP

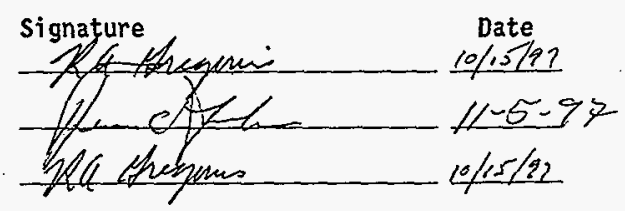

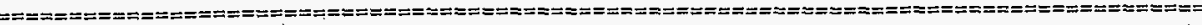

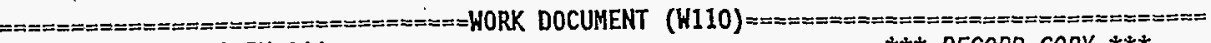

$* * *$ RECORD COPY ***

$* * *$ RECORD COPY ***

$16 \cap f 27$ 
HNF-1774

Rev. 0

Appendix C Fan Performance Data Sheets 


\section{DATA SHEET}

\section{ICS 3I-324-849 ATACHMENT}

IEST NO. I

ZONE I EXHAUST FAN \#973/BUILDING 324

DATE $9 \cdot 27-27$

ITR FLOW INSTURMENT USED MICRO

WHSL CODE \#

IAST WHSL CALIBRATION DATE $8-19-9 \%$

DUCT SIZE_ 37 IN. DIA.

DU்CT AREA $\quad 7.47 \quad \mathrm{FT}^{2}$

\begin{tabular}{|c|c|c|c|c|}
\hline $\begin{array}{l}\text { DATA } \\
\text { POINT } \\
\text { NO. }\end{array}$ & $\begin{array}{l}\text { PITOT } \\
\text { TRAVERSE } \\
\text { POINTS } \\
\end{array}$ & $\begin{array}{l}\text { VELOCITY } \\
\text { PRESSURE } \\
\text { IN. WG. }\end{array}$ & $\begin{array}{c}\text { VELOCITY } \\
\text { FPM }\end{array}$ & \multirow{5}{*}{$\begin{array}{ll}\text { FAN INLET SP }-6.67 & \text { IN. WG. } \\
\text { FAN OUTLET SP }+.037 & \text { IN. WG. } \\
\text { FAN INLET VP. } .002 & \text { IN. WG. } \\
\text { FAN SP } 6.705 & \text { IN. WG. }\end{array}$} \\
\hline 1 & 1" & 0 & 0 & \\
\hline 2 & . 3" & 0 & 0 & \\
\hline 3 & $57 / 16^{\prime \prime}$ & 012 & 439 & \\
\hline 4 & $83 / 8^{\prime \prime}$ & 020 & 566 & \\
\hline 5 & $125 / 8^{\prime \prime}$ & .026 & 645 & \multirow{4}{*}{$\begin{array}{l}\text { NOTE: } \\
\text { *FAN SP }=\mathrm{SP}_{\text {OUTLET }}-\mathrm{SP}_{\mathrm{IMLET}}-\mathrm{VP}_{\mathrm{INIET}} \\
\quad \mathrm{SP} \text { (static pressure) }\end{array}$} \\
\hline 6 & $243 / 8^{\prime \prime}$ & 004 & 253 & \\
\hline 7 & $285 / 8^{\prime \prime}$ & 0 & 0 & \\
\hline 8 & $319 / 16^{\prime \prime}$ & 0 & 0 & \\
\hline 9 & $34^{\prime \prime}$ & 0 & & \multirow{2}{*}{$\begin{array}{l}\text { VP (velocity pressure) } \\
\text { *Industrial Ventilation Handbook 18th Edition }\end{array}$} \\
\hline 10 & $36^{\prime \prime}$ & .014 & 474 & \\
\hline
\end{tabular}

AVERAGE VELOCITY _194_FPM

TOTAL AIR FLOW RATE 1449

COMMENTS: 


\section{DATA SHEET}

JCS 3I-324-849 ATACHMENT

IEST NO. II

AIR FLOW INSTURMENT USED $M 1 C \Omega O$

ZAST WHSL CAIIBRATION DATE $8-19-97$

DUCT SIZE_ 37 IN. DIA.
WHSL CODE \#

$$
702-25-09-019
$$

DUCT AREA $\quad 7.47 \quad F^{2}$

\begin{tabular}{|c|c|c|c|c|}
\hline $\begin{array}{c}\text { DATA. } \\
\text { POINT } \\
\text { NO. }\end{array}$ & $\begin{array}{c}\text { PITOT } \\
\text { TRAVERSE } \\
\text { POINTS } \\
\end{array}$ & $\begin{array}{c}\text { VELOCITY } \\
\text { PRESSURE } \\
\text { IN. WG. } \\
\end{array}$ & $\begin{array}{c}\text { VELOCITY } \\
\text { FPM }\end{array}$ & \multirow{11}{*}{$\begin{array}{ll}\text { FAN INLET SP }-7.05 & \text { IN. WG. } \\
\text { FAN OUTLET SP } .00 L & \text { IN. WG. } \\
\text { FAN INLET VP_.0OL } & \text { IN. WG. } \\
\text { FAN SP } 7.047 & \text { IN. WG. }\end{array}$} \\
\hline 1 & 1" & 0 & 0 & \\
\hline 2 & 3" & .002 & 179 & \\
\hline 3 & $57 / 16^{11}$ & .005 & 283 & \\
\hline 4 & $83 / 8^{\prime \prime}$ & .006 & 310 & \\
\hline 5 & $125 / 8^{\prime \prime}$ & .005 & 283 & \\
\hline 6 & $243 / 8^{\prime \prime}$ & .013 & 4552 & \\
\hline 7 & $285 / 8^{\prime \prime}$ & .003 & 219 & \\
\hline 8 & $319 / 16^{\prime \prime}$ & .017 & 522 & \\
\hline 9 & $34^{\prime \prime}$ & .001 & 127 & \\
\hline 10 & $36^{\prime \prime}$ & 0 & 0 & \\
\hline
\end{tabular}

AVERAGE VELOCITY $\quad 238$ FPM

TOTAL ATR FLOW RATE $1,778 \cdots C F M$

COMAMENTS: 
DATA SHEET

JCS 3I-324-849 ATACHMENT

$\operatorname{TEST} N \mathrm{NI}$

AIR FLOW INSTURMENT USED $2 m / C \Omega_{2} \mathrm{O}$

LAST WHSL CALIBRATION DATE $8-19-97$

DUCT SIZE_ 37 IN. DIA.
WHSL CODE\#

$$
702-28-09-019
$$

DUCT AREA $\quad 7.47 \quad$ FT $^{2}$

\begin{tabular}{|c|c|c|c|c|}
\hline $\begin{array}{c}\text { DATA } \\
\text { POINT } \\
\text { NO. } \\
\end{array}$ & $\begin{array}{c}\text { PITOT } \\
\text { TRAVERSE } \\
\text { POINTS } \\
\end{array}$ & $\begin{array}{c}\text { VEIOCITY } \\
\text { PRESSURE } \\
\text { NN. WG. }\end{array}$ & $\begin{array}{l}\text { VELOCITY } \\
\text { FPM }\end{array}$ & FAN STATIC PRESSURE \\
\hline 1 & $1^{\prime \prime}$ & .015 & 491 & FANINLET SP -7.44 \\
\hline 2 & 3" & .018 & 537 & FAN OUTLET SP $=.052$ IN. WG. \\
\hline 3 & $57 / 16^{\prime \prime}$ & 016 & 507 & FANINLET VP. $.0 / 6$ \\
\hline 4 & $83 / 8^{\prime \prime}$ & .017 & 522 & FAN SP $7.48 / \ldots$ IN. WG. \\
\hline 5 & $125 / 8^{\prime \prime}$ & .016 & 507 & \\
\hline 6. & $243 / 8^{\prime \prime}$ & .018 & 537 & NOTE: \\
\hline 7 & $285 / 8^{\prime \prime}$ & .015 & 491 & ${ }^{*} \mathrm{EAN} S \mathrm{SP}=\mathrm{SP}_{\text {OUTLET }}-\mathrm{SP}_{\mathrm{NLET}}-\mathrm{VP}_{\mathrm{INIET}}$ \\
\hline 8 & $319 / 16^{\prime \prime}$ & .007 & 3.25 & SP (static pressure) \\
\hline 9 & $34^{\prime \prime}$ & .020 & $566^{\circ}$ & VP (velocity pressure) \\
\hline 10 & $36 "$ & .026 & 645 & *Industrial Ventilation Handbook 18th Edition \\
\hline
\end{tabular}

AVERAGE VELOCITY _ $5 / 4$ FPM

TOTAL ATR FLOW RATE $3,8 / \not 0 \quad$ CFM

COMNENTS: 
DATA SHEET

JCS 3I-324-849 ATACHMENT

TEST NO. IL

ARR FLOW INSTURMENT USED M/SRO

IAST WHSL CALTBRATION DATE $8-19-97$

WHSL CODE \#

$$
702-28-09-019
$$

DUCT SIZE_ 37 IN. DIA.

DUCT AREA $\quad 7.47 \quad$ FT $^{2}$

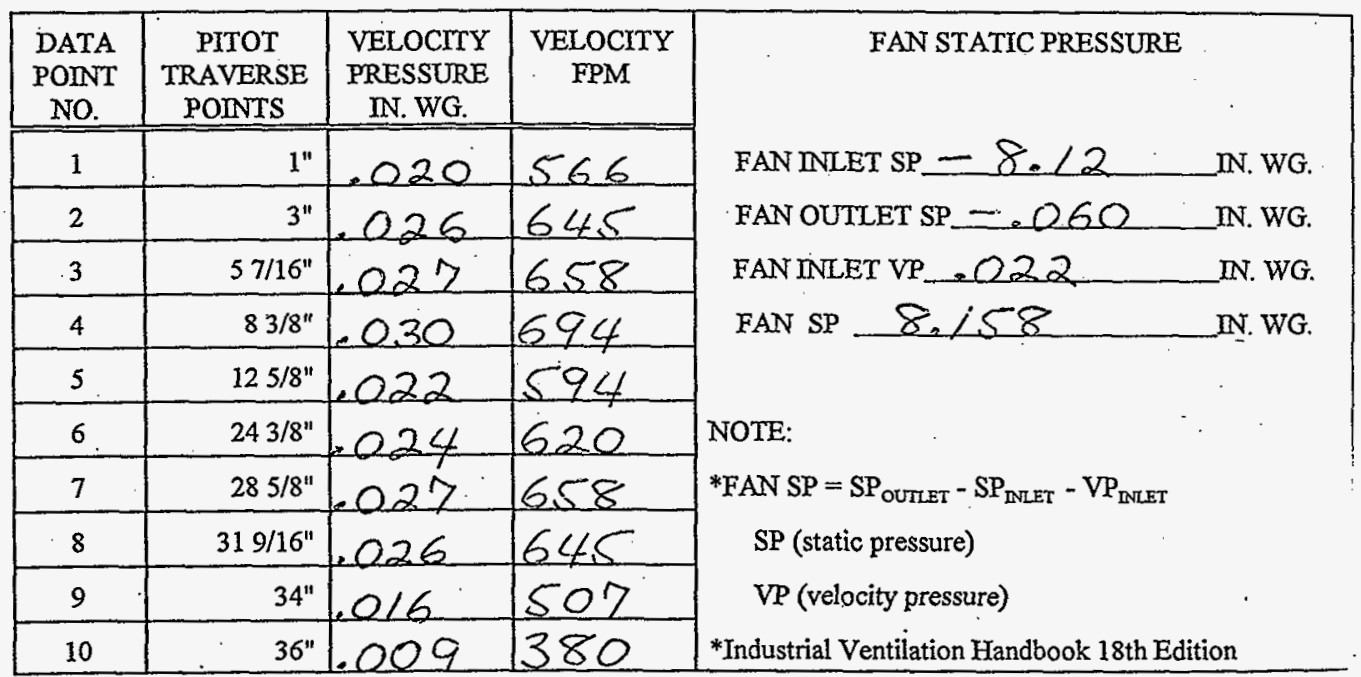

AVERAGE VELOCITY 597 FPM

TOTAL AIR FLOW RATE $44460 \quad$ CFM

COMMENTS: 
DATA SHEET

JCS 3I-324-849 ATACHMENT

IESTNO. I

IIR FLOW INSTURMENT USED_ZRICKLO

WHSL CODE \#

ZAST WHSL CAIIBRATION DATE_ $8-19-97$

\begin{tabular}{|c|c|c|c|c|}
\hline $\begin{array}{l}\text { DATA } \\
\text { POINT } \\
\text { NO. }\end{array}$ & $\begin{array}{l}\text { PITOT } \\
\text { TRAVERSE } \\
\text { POINTS } \\
\end{array}$ & $\begin{array}{c}\text { VELOCITY } \\
\text { PRESSURE } \\
\text { IN. WG. }\end{array}$ & $\begin{array}{c}\text { VELOCITY } \\
\text { FPM }\end{array}$ & \multirow{4}{*}{$\begin{array}{ll}\text { FAN INLET SP }-8.78 & \text { IN. WG. } \\
\text { FAN OUTLET SP }-.077 & \text { IN. WG. } \\
\text { FAN INLET VP_.031 } & \text { IN. WG. }\end{array}$} \\
\hline 1 & $1^{\prime \prime}$ & .024 & 620 & \\
\hline 2 & $3^{n}$ & .033 & 1728 & \\
\hline 3 & $57 / 16^{\prime \prime}$ & .034 & 738 & \\
\hline 4 & $83 / 8^{\prime \prime}$ & .035 & 749 & \multirow{2}{*}{ FAN SP $8.826 \quad$ IN. WG. } \\
\hline 5 & $125 / 8^{\prime \prime}$ & $.0,30$ & 694 & \\
\hline 6 & $243 / 8^{\prime \prime}$ & .030 & 694 & \multirow{5}{*}{$\begin{array}{l}\text { NOTE: } \\
\text { *FAN SP = SP } \\
\quad \mathrm{SP} \text { (static pressure) } \\
\mathrm{VP} \text { (velocity pressure) } \\
\text { *Industrial Ventilation Handbook } 18 \text { th Edition }\end{array}$} \\
\hline 7 & $285 / 8^{\prime \prime}$ & .035 & 749 & \\
\hline 8. & $319 / 16^{\prime \prime}$ & .034 & 738 & \\
\hline 9 & 34" & .020 & 566 & \\
\hline 10 & $36^{\prime \prime}$ & 1.039 & 791 & \\
\hline
\end{tabular}

AVERAGE VELOCITY 707 FPM

TOTAL AIR FLOW RATE $5,28 /$ CFM

COMMENTS: 
DATA SHEET

JCS 3I-324-849 ATACHMENT

[EST NO. TZL

AIR FLOW INSTURMENT USED

201020

CAST WHSL CALIBRATION DATE $8-19-97$

DUCT SIZE_ 37 IN. DIA.
WHSL CODE \#

$302-25-09-019$

DUCT AREA $\quad 7.47$

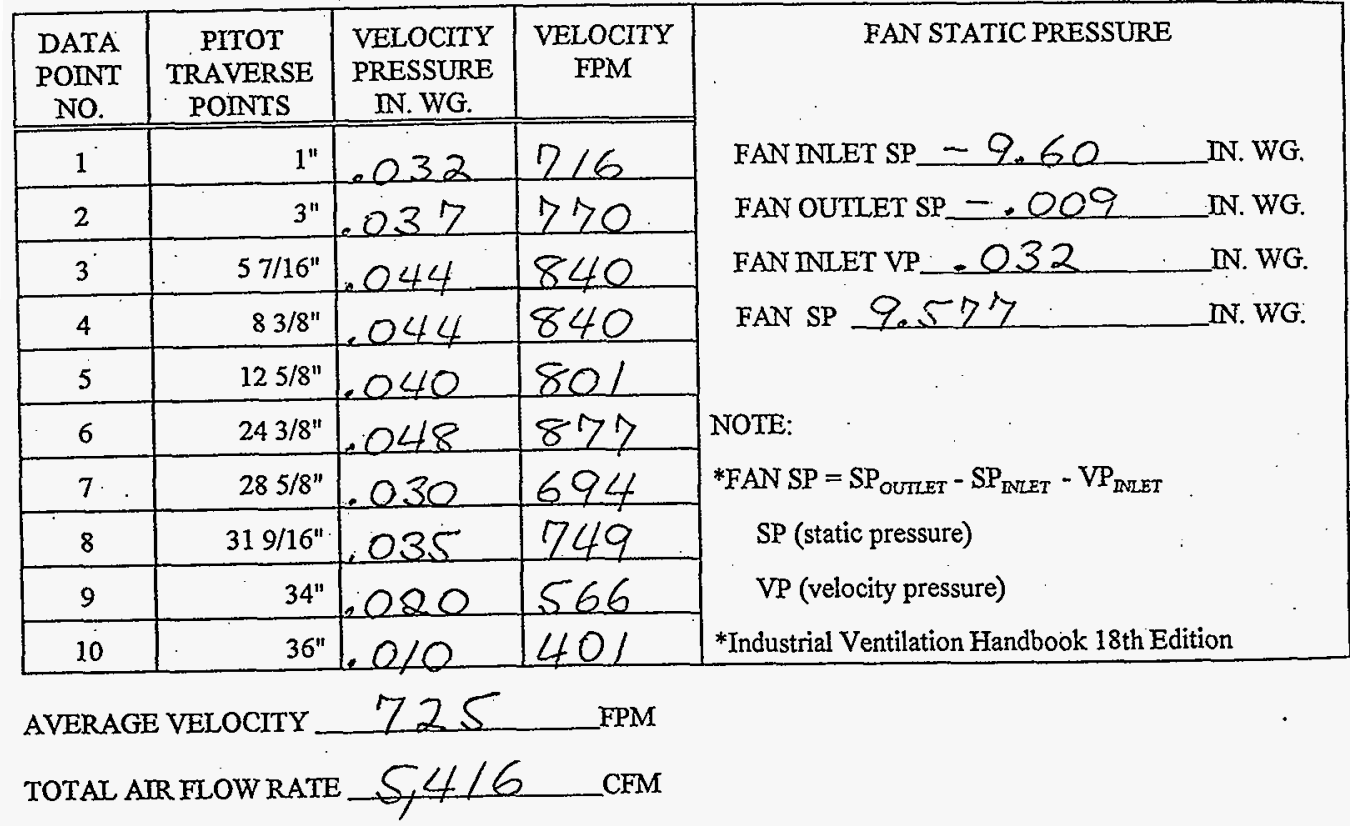

COMMENTS: 
DATA SHEET

JCS 3I-324-849 ATACHMENT

TEST NO.VII $-\frac{3}{4} \%$ ZONE I EXHAUST FAN \#973/BUILDING 324. DATE, $9-27-97$ AIR FLOW INSTURMENT USED $221 C$ CO WHSL CODE \# LAST WHSL CALIBRATION DATE $\&-19-9 z$ $702-28-0 \overline{8-019}$ DUCT SIZE $\quad 37$ IN. DIA. DUCT AREA $\quad 7.47 \quad$ FT $^{2}$

\begin{tabular}{|c|c|c|c|c|}
\hline $\begin{array}{l}\text { DATA } \\
\text { POINT } \\
\text { NO. } \\
\end{array}$ & $\begin{array}{c}\text { PITOT } \\
\text { TRAVERSE } \\
\text { POINTS } \\
\end{array}$ & $\begin{array}{c}\text { VELOCITY } \\
\text { PRESSURE } \\
\text { IN. WG. }\end{array}$ & $\begin{array}{c}\text { VELOCITY } \\
\text { FPM }\end{array}$ & FAN STATIC PRESSURE \\
\hline $\mathrm{i}$ & $1 "$ & .035 & 749 & FAN INLET SP -10.0$\rangle \quad$ IN. WG. \\
\hline 2 & 3" & .041 & 811 & FAN OUTLET SP $\not .045 \quad$ MN. WG. \\
\hline 3 & $57 / 16^{\prime \prime}$ & .044 & 840 & FAN INLET VP.. .042 \\
\hline 4 & $83 / 8 "$. & .049 & 887 & FAN SP $10.073 \quad$ IN. WG. \\
\hline 5 & $125 / 8^{\prime \prime}$ & .044 & 840 & . \\
\hline 6 & $243 / 8^{\prime \prime}$ & .044 & 840 & NOTE: \\
\hline 7 & $285 / 8^{\prime \prime}$ & .052 & 913 & $* F A N S P=S P_{\text {oUTIET }}-S P_{\text {INLET }}-V_{\text {MNLET }}$ \\
\hline 8 & $319 / 16^{\prime \prime}$ & .043 & 830 & SP (static pressure) \\
\hline 9 & $34^{\prime \prime}$ & .020 & 566 & VP (velocity pressure) \\
\hline 10 & $36^{\prime \prime}$ & .059 & 973 & *Industrial Ventilation Handbook 18 th Edition \\
\hline
\end{tabular}

AVERAGE VELOCITY 825 FPM TOTAL AIR FLOW RATE $6.163 \quad \mathrm{CFM}$ COMMENTS: 


\section{DATA SHEET}

\section{JCS 3I-324-849 ATACHMENT}

IEST NO. UII $\frac{7}{8}$ ZONE I EXHAUST FAN \#973/BULDING 324

AIR FLOW INSTURMENT USED $2 \mathrm{~N} / \mathrm{C} \mathrm{K}$

LAST WHSL CALIBRATION DATE $8=19-97$

DUCT SIZE _ 37 IN. DIA.
WHSL CODE \#

$102-28-0 \overline{-019}$.

DATE $9-27-97$

DUCT AREA $7.47 \quad F^{2}$

\begin{tabular}{|c|c|c|c|c|}
\hline $\begin{array}{l}\text { DATA } \\
\text { POINT } \\
\text { NO. } \\
\end{array}$ & $\begin{array}{l}\text { PITOT } \\
\text { TRAVERSE } \\
\text { POINTS } \\
\end{array}$ & $\begin{array}{c}\text { VELOCITY } \\
\text { PRESSURE } \\
\text { IN. WG. } \\
\end{array}$ & $\begin{array}{l}\text { VELOCITY } \\
\text { FPM }\end{array}$ & FAN STATIC PRESSURE \\
\hline 1 & $1^{\prime \prime}$ & -022 & 594 & FAN INLET SP $=\angle 0.02$ \\
\hline 2 & 3" & .044 & 840 & FAN OUTLET SP $\pm .070 \quad$ IN. WG. \\
\hline 3 & $57 / 16^{\prime \prime}$ & .047 & 868 & FAN INLET VP_. 035 \\
\hline 4 & $83 / 8^{\prime \prime}$ & .050 & 896 & FAN SP 10.055 \\
\hline 5 & $125 / 8^{\prime \prime}$ & .048 & 871 & \\
\hline 6 & $243 / 8^{\prime \prime}$ & .043 & 830 & NOTE: \\
\hline 7 & $285 / 8^{\prime \prime}$ & .050 & 896 & ${ }^{*} \mathrm{FAN} \mathrm{SP}=\mathrm{SP}_{\text {OUILET }}-\mathrm{SP}_{\mathrm{INLET}}-\mathrm{VP}_{\text {INLET }}$ \\
\hline 8 & $319 / 16^{\prime \prime}$ & .044 & 840 & SP (static pressure) \\
\hline 9 & 34" & .030 & 694 & VP (velocity pressure) \\
\hline 10 & $35^{\prime \prime}$ & .002 & 179 & *Industrial Ventilation Handbook 18 th Edition \\
\hline
\end{tabular}

AVERAGE VELOCITY___ $75 /$ FPM

TOTAL AIR FLOW RATE $5,6 / 0 \quad$ CFM

COMMENTS: 
DATA SHEET

JCS 3I-324-849 ATACHMENT

ZEST NO.I $100 \%$ ZONE I EXHAUST FAN \#973/BULLDING 324

UIR FLOW INSTURMENT USED $2 / \subset \bumpeq 0$

¿AST WHSL CALIBRATION DATE $8-19-97$

JUUCT SIZE $\quad 37$ IN. DIA.
DATE $9-27-67$

WHSL CODE \#

$702-28-\overline{09-019}$

DUCT AREA $\quad 7.47 \quad$ FT $^{2}$

\begin{tabular}{|c|c|c|c|c|}
\hline $\begin{array}{c}\text { DATA } \\
\text { POINT } \\
\text { NO. }\end{array}$ & $\begin{array}{c}\text { PITOT } \\
\text { TRAVERSE } \\
\text { POINTS } \\
\end{array}$ & $\begin{array}{l}\text { VELOCITY } \\
\text { PRESSURE } \\
\text { IN. WG. }\end{array}$ & $\begin{array}{c}\text { VELOCITY } \\
\text { FPM }\end{array}$ & FAN STATIC PRESSURE \\
\hline 1 & $1 "$ & $=080$ & $1 / 33$ & FAN INLET SP -9.96 \\
\hline 2 & 3" & .087 & 1181 & FAN OUTLET SP $t=070 \quad$ IN. WG. \\
\hline 3 & $57 / 16^{\prime \prime}$ & .092 & $12 / 5$ & FAN INLET VP_. $084 \quad$ N. WG. \\
\hline 4 & $83 / 8^{\prime \prime}$ & .099 & 1260 & FAN SP $9,946 \ldots$ IN.WG. \\
\hline 5 & $125 / 8^{\prime \prime}$ & .090 & 1202 & \\
\hline 6 & $243 / 8^{\prime \prime}$ & .090 & 1202 & NOTE: \\
\hline 7 & $285 / 8^{\prime \prime}$ & 0.96 & .241 & *FAN SP $=\mathrm{SP}_{\text {oUTLET }}-\mathrm{SP}_{\text {NLET }}-\mathrm{VP}_{\text {INLET }}$ \\
\hline 8 & $319 / 16^{\prime \prime}$ & .092 & 1215 & SP (static pressure) \\
\hline 9 & $34^{\prime \prime}$ & .069 & 1052 & VP (velocity pressure) \\
\hline 10 & $36^{\prime \prime}$ & 1.053 & 922 & *Industrial Ventilation Handbook 18 th Edition \\
\hline
\end{tabular}

AVERAGE VELOCITY _/, 162 FPM

TOTAL AIR FLOW RATE 8,680 . CFM

COMMENTS:

AIR BALANCE TECH. $9-27-97$ 


\section{DATA SHEET}

\section{JCS 3I-324-849 ATACHMENT}

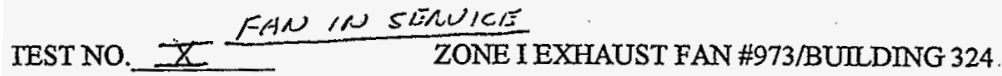

DATE $9-2>-97$

AIR FLOW INSTURMENT USED

2016,20

WHSL CODE \#

$302-28-0 \overline{09-019}$

LAST WHSL CALIBRATION DATE $8-19-97$

DUCT SIZE__37 IN. DIA.

DUCT AREA_ $7.47 \quad \mathrm{FT}^{2}$

\begin{tabular}{|c|c|c|c|c|}
\hline $\begin{array}{c}\text { DATA } \\
\text { POINT } \\
\text { NO. } \\
\end{array}$ & $\begin{array}{c}\text { PITOT } \\
\text { TRAVERSE } \\
\text { POINTS } \\
\end{array}$ & $\begin{array}{c}\text { VELOCITY } \\
\text { PRESSURE } \\
\text { IN. WG. } \\
\end{array}$ & $\begin{array}{l}\text { VELOCITY } \\
\text { FPM }\end{array}$ & FAN STATIC PRESSURE \\
\hline 1 & $1^{\prime \prime}$ & .090 & 1202 & FAN INLET SP $=10.50 \quad$ IN. WG. \\
\hline 2 & $3^{\prime \prime}$ & .116 & 1364 & FAN OUTLET SP $\perp .040 \quad$ IN. WG. \\
\hline 3 & $57 / 16^{11}$ & .109 & 1322 & FAN INLET VP.,$/ / 8$ \\
\hline 4 & $83 / 8^{\prime \prime}$ & .130 & 1444 & FAN SP $\angle 0.422 \quad$ IN. WG. \\
\hline 5 & $125 / 8^{\prime \prime}$ & .112 & 1340 & \\
\hline 6 & $243 / 8^{\prime \prime}$ & .104 & 1292 & NOTE: \\
\hline 7 & $285 / 8^{\prime \prime}$ & .130 & $1<444$ & ${ }^{*} \mathrm{FAN} \mathrm{SP}=\mathrm{SP}_{\text {OUILET }}-\mathrm{SP}_{\mathrm{INLET}}-\mathrm{VP}_{\mathrm{INLET}}$ \\
\hline 8 & $319 / 16^{\prime \prime}$ & 161 & 1607 & SP (static pressure) \\
\hline 9 & $34^{\prime \prime}$ & .140 & 1499 & VP (velocity pressure) \\
\hline 10 & $36^{\prime \prime}$ & .107 & $\angle 3 / 0$ & *Industrial Ventilation Handbook 18 th Edition \\
\hline
\end{tabular}

AVERAGE VELOCITY _, 380 FPM

TOTAL AIR FLOW RATE $\not 0,309$ CFM

COMMENTS: 


\section{DISTRIBUTION SHEET}

\begin{tabular}{|c|c|c|c|c|c|}
\hline \multirow{2}{*}{$\begin{array}{l}\text { To } \\
\text { Distribution } \\
\end{array}$} & \multirow{2}{*}{\multicolumn{3}{|c|}{$\begin{array}{l}\text { From } \\
\text { M. B. Enghusen }\end{array}$}} & \multicolumn{2}{|c|}{ Page tof 1} \\
\hline & & & & \multicolumn{2}{|c|}{ Date November 6,1997} \\
\hline \multirow{2}{*}{\multicolumn{3}{|c|}{$\begin{array}{l}\text { Project Title/Work Order } \\
324 \text { Facility Stabilization Project }\end{array}$}} & & \multicolumn{2}{|c|}{ EDT No. 611750} \\
\hline & & & & \multicolumn{2}{|c|}{ ECN No. N/A } \\
\hline Name & MSIN & $\begin{array}{l}\text { Text } \\
\text { With All } \\
\text { Attach. }\end{array}$ & Text Only & $\begin{array}{l}\text { Attach./ } \\
\text { Appendix } \\
\text { Only }\end{array}$ & $\begin{array}{l}\text { EDT/ECN } \\
\text { Only }\end{array}$ \\
\hline $\begin{array}{l}\text { Central Files (2) (0rig }+1) \\
\text { Docket Files (2) }\end{array}$ & $\begin{array}{l}\mathrm{B} 1-07 \\
\mathrm{~B} 1-17\end{array}$ & $\begin{array}{l}\mathrm{X} \\
\mathrm{X}\end{array}$ & & & \\
\hline \multicolumn{6}{|l|}{ B\&W Hanford Company } \\
\hline $\begin{array}{l}\text { M. B. Enghusen (5) } \\
\text { G. O. Hayner } \\
\text { A. M. Homer } \\
\text { J. M. Steffen } \\
\text { M. S. Wright }\end{array}$ & $\begin{array}{l}\text { L1-02 } \\
\text { L5-65 } \\
\text { L6-57 } \\
\text { N1-47 } \\
\text { L1-02 }\end{array}$ & $\begin{array}{l}X \\
X \\
X \\
X \\
X\end{array}$ & & & . \\
\hline \multicolumn{6}{|l|}{ Fluor Daniel Hanford } \\
\hline $\begin{array}{l}\text { C. B. Evans } \\
\text { H. Z. Dokuzoguz }\end{array}$ & $\begin{array}{l}\text { B1-19 } \\
\text { N1-26 }\end{array}$ & $\begin{array}{l}\mathrm{X} \\
\mathrm{X}\end{array}$ & & & \\
\hline \multicolumn{3}{|c|}{ U.S. Department of Energy-Richland Operations Office } & & & \\
\hline $\begin{array}{l}\text { B. L. Charboneau } \\
\text { D. W. Templeton } \\
\text { D. C. Langstaff }\end{array}$ & $\begin{array}{l}\text { L1-02 } \\
\text { L1-02 } \\
\text { R3-79 }\end{array}$ & $\begin{array}{l}\mathrm{X} \\
\mathrm{X} \\
\mathrm{X}\end{array}$ & & & \\
\hline
\end{tabular}

